\title{
Chapter 16. Continuity and Change in the Austronesian Transition to Islam and Christianity
}

\section{Anthony Reid}

Commercial links and a common orientation towards maritime trade continued to bind Southeast Asian Austronesian communities together in historical times, and the spread of Islam is regarded as a consequence of these cultural ties. Islam required many changes in traditional Austronesian social and religious practices, as did Christianity, but the strength of Austronesian tradition, reinforced greatly by the continuing use of the Austronesian languages as vernaculars, imposed a two-way dialogue on the process.

\section{Austronesian Boundaries}

A Samoan deposited in (say) Madura might well conclude that it was Islam that most profoundly distinguished Indonesian culture from his own. In dress, diet, naming, social and domestic relations as well as belief and ritual, Islam has taken the majority of today's Austronesians in a distinctive direction. In consequence they would probably see less reason to identify with our Samoan than with non-Austronesian Muslims in South and West Asia. One might reasonably conclude that the conversion by 1650 of most lowland areas of the archipelagoes we now know as Indonesia and the Philippines to Islam or Catholicism had created the most fundamental cleavages between Austronesians. From these transitions, however initially qualified, there was no going back. No subsequent influence from Holland, China, Britain, Japan or America could ever overturn these identities as Muslim or Catholic, whatever they were held to mean in different times and places.

This would, however, be only part of the story. The two prosyletizing scriptural religions were by no means the only, nor even the first, of the consequences for Southeast Asia's Austronesians of proximity to the great Eurasian land mass. Others have spoken eloquently of the transitions wrought in Southeast Asia by Sanskrit terminology and Indian political and philosophical ideas, as these were selectively adapted by Austronesians. I want to draw attention also to the commercial and diplomatic connectedness within and beyond Southeast Asia which predated and underlay the advance of Islam among Austronesians.

When the ancestors of the Polynesians struck out to the east of the Indonesian Archipelago, they sailed off the edge of the known world. For more than a 
thousand years before the eighteenth century exploration of the Pacific, the Austronesians who remained in Southeast Asia were significant players in a series of interlocking trade networks which stretched from eastern Indonesia to China and Japan in the north and to Portugal and Ireland in the west. We know this not so much from the ambiguous geographical information of Ptolemy and his Chinese contemporaries as from the arrival of the products of eastern Indonesia in the markets of the world.

Only after their arrival in Southeast Asia did Europeans discover just where the spices they had been seeking came from:

The Malay merchants say that God made Timor for sandalwood and Banda for [nutmeg and] mace and Maluku for cloves, and that this merchandise is not known anywhere in the world except in these places (Pires 1515:204).

These points marked precisely where the southeastern boundary of the Eurasian world-system lay. Cloves, nutmeg and sandalwood were sent to the north and west in small quantities from as early as Roman and Han times. Records of shipments reaching Europe are continuously available from only the tenth century, and they show a trickle of nutmeg and clove rising to a steady stream at the end of the fourteenth century. Austronesians, with intermittent stimulus from Chinese, were the carriers of these spices around the archipelago, to entrepôts such as Sri Vijaya, Melaka, Patani and Banten. By travelling frequently as far as Maluku and Timor, they kept these peripheries on the known map of world commerce.

Beyond that, to the east and south, lay darkness. In the perspective of Asian traders the Indonesian Archipelago represented "the outer edge of the world" (Pinto 1578:393; also Wolters 1970:23-24). Of course there was some exchange across the Arafura and Timor seas, with a few slaves and birds of paradise from New Guinea and the surrounding islands being traded as far as Java. In comparison with the intense commercial interest focused on Maluku and Timor, however, the low level of interaction beyond is extraordinary.

Austronesians were among the great sailors of Asia, and their involvement in maritime commerce was one of the themes that maintained a sense of common interest among seemingly culturally diverse Austronesians. As well as carrying their own produce into world markets, Austronesians commanded all the sea routes between east Asia and the rest of Eurasia. Whether shipping passed through the Melaka or the Sunda or the Lombok and Makassar Straits; whether portages were made across the Malay Peninsula from Melaka, from Kedah or from Tennasserim; whether traffic to and from China took on water and supplies along the Cham coast of Indochina and the east coast of the Malay Peninsula, or in the Philippines and eastern Borneo, or along the west coast of Borneo and 
Java; Austronesians were directly involved. In the long and often intense commercial and diplomatic relationship between Southeast Asia and China it was Austronesians who took most of the initiatives, at least until the southern Sung dynasty (1127-1279) stimulated the creation of a Chinese seagoing fleet (Wolters 1970:19-42). The Malay culture hero, Hang Tuah, was appropriately depicted sailing, trading and fighting for his king in China, India and the Middle East as well as Java and Siam. While the Malayo-Muslim maritime tradition is well known, it is worth recalling Dampier's praise also for still-Hindu Chams, one of whose vessels he encountered in the Gulf of Siam in 1687:

They were of the idolators, Natives of Champa, and some of the briskest, most sociable, without Fearfulness or Shyness, and the most neat and dexterous about their Shipping, of any such I have met with in all my Travels (Dampier 1697:272).

How else than through this common commitment to maritime commerce does one explain the curious ways in which Malays, Javanese, Chams and Tagalogs were tied to each other? Champa and Majapahit exchanged royal princesses and diplomatic missions in the fourteenth century, and a Cham king chose Java as his refuge from Vietnamese pressure on the Cham capital in 1318 (Robson 1981:276). Both Malay and Javanese traditions make much of the Cham connection. The Sejarah Melayu (1612:135) claims that a ruler of Champa journeyed to Majapahit to make his homage, fathering there a child by a Majapahit princess. This child grew up to become the penultimate ruler of Champa before the capital, Vijaya, fell to the conquering Vietnamese.

Javanese tradition asserts that it was through a Cham princess married to the king of Majapahit, and her brother Raden Rahmat, that Islam entered the Javanese court. To complete the Austronesian triangle, Rahmat took as his wife a lady of Tuban named Nyai Ageng Manila - perhaps evidence of Philippine birth (Babad Tanah Jawi:20-21). Although there were certainly Muslims in Champa in the fifteenth century, the Cham ruling class was still Hindu at the time of the Vietnamese conquest of Vijaya (Qui Nhon), which Vietnamese sources date to 1471. The Malay royal chronicle claims that the Hindu aristocrats who fled the Vietnamese took refuge not in nearby Hindu-Buddhist Cambodia but among Muslim fellow-Austronesians in Melaka and north Sumatra (Sejarah Melayu 1612:136-137). The king of Champa, with his capital further south in Phanrang, remained a Hindu until at least 1607, but he was nevertheless closely allied with Malay Johor against Vietnamese, Khmer and Portuguese (Matelief 1608:120-121; Manguin 1979:269).

The Cham diaspora of traders, warriors and refugees in the sixteenth and seventeenth centuries was Muslim or in process of becoming so. Muslim Chams were among those battling the Portuguese in the South China Sea and aiding Demak's holy wars in Java in the sixteenth century, and helping even distant 
Makassar in the seventeenth (Pinto 1578:107, 386; Sja'ir Perang Mengkasar: 146-147). Malays and Chams were so closely aligned during the conflicts of seventeenth-century Cambodia that their Iberian enemies thought they were one people.

The first European reports on the Tagalogs classify them as "Luzons" (Port. Lucoes), a nominally Muslim commercial people trading out of Manila, and "almost one people" with the Malays of Brunei (Pires 1515:134). One of these Luzons commanded the Brunei fleet in 1521 (Pigafetta 1524:58-59), and another was named head (temenggong) of the Malays remaining in Melaka after the Portuguese conquest in 1511 (Pires 1515:134, 281). As well as their substantial trade with Melaka, the Luzons were collecting sandalwood in Timor when Magellan's ship reached there (Pigafetta 1524:94), no doubt to supply the Chinese trade. Luzons were well represented in the polyglot Muslim fleets which did battle with the Portuguese in the South China Sea during the sixteenth century, and one of them held Aru (northeast Sumatra) for the crusading Sultan of Aceh in 1540 (Pinto 1578:49, 107, 112). Pinto, our source for much of this, also mentions Luzons among the anti-Muslim warriors of the Batak king, in 1538 (ibid.:26), suggesting they could be mercenaries valued by all sides. Luzons disappear from descriptions of the archipelago after the Spanish conquest of Manila in 1571, presumably assimilating to the Malay diaspora.

We should also recall the intermingling of Javanese and Malays, especially in Melaka where the Hikayat Hang Tuah admitted that the Malays were all "half-Javanese" (Winstedt 1969:38), and where the royal chronicle was studded with Javanese passages. The very categories Jawah and Jawi referred as frequently to Sumatra or Malays as to Javanese until European labels began to prevail. More surprisingly, Madagascar's interaction with the Indonesian Archipelago was still remembered in the sixteenth century, when the Portuguese found there "many brown and Javanised natives who say they are descended from them [Javanese]", which they attributed to Javanese seafarers having traveled across the Indian Ocean (Couto 1645, IV, iii:169).

It appears, then, that commercial links and a common orientation towards maritime trade continued to bind the Austronesians who "remained behind" on the fringes of Eurasia to each other, in advance of and apart from Islam or Christianity. The spread of Islam to most of the Austronesians of Southeast Asia can be seen as a consequence as much as it was a cause of this common involvement in maritime commerce.

\section{Islamization as Change}

The initial threshold of entry into the house of Islam was deliberately low - to recite the shahada ("there is no god but God and Muhammad is His Prophet"); to undergo circumcision; and to abandon the consumption of pork. 
Understanding of the message of Islam could come later. In urging de Houtman to take the simple step which would save his life in Aceh, even if he could not appreciate the body of Islamic doctrine, a Muslim scholar there used the image of a master shipwright who had first to lay down the keel of the ship though he could not yet see the whole pattern of the vessel (a metaphor more appropriate to Austronesian than to Dutch shipbuilding) (de Houtman 1601:99). It was these external symbols of adherence to the faith which were held to be the essential requirements of entry. No internal assent to a creed or confession of past errors was called for. Europeans who encountered peoples recently converted, like the "Lutao" of Mindanao and northern Maluku, often thought these externals were all there was:

Never is a Lutão found who has not been circumcised, or one who eats pork - and it is this which constitutes their Mahometanism ... for they do not know what the Koran is (Diaz 1718:321; cf. Legazpi 1569:60-61).

A Muslim source, the Hikayat Patani (75) also made the point about the first Patani ruler to adopt Islam: "He gave up worshipping idols and eating pork, but apart from that he did not alter a single one of his kafir habits".

This pattern has led many authors to see conversion as an inappropriate term for the first steps towards Islamic faith. Merle Ricklefs (1979) depicted Islamization not as a step but as an ongoing journey in "Six centuries of Islamization in Java". This should not be taken to mean, however, that change was imperceptible, steady, or unidirectional. Rather, I would argue, it was made up of numerous conversions to the external ideal and almost as many reversions towards the bedrock of Austronesian habits. Changes were profound, and the first step often the most profound. The cost of entry into Islam should not be minimized by a modern sensibility which sees religion as a matter of personal conviction and piety. It involved a change of identity symbolized by the abandonment of the pig-eating which had provided Austronesians with not only their major meat source but also the stuff of sacrifice and feasting.

Pig-eating was a major obstacle to conversion in all the cases for which there is first-hand evidence. In South Sulawesi Bugis and Portuguese sources agree that Islam failed to make headway in the sixteenth century because of its ban on pork and other foods (Dias 1559:306; Noorduyn 1955:105-106). A pious legend had one Makassarese chief threatened with jihad declare that he would not accept Islam even if rivers flowed with blood, as long as there were pigs to eat in the forests of Bulo-bulo. Of course that very night the pigs disappeared by divine intervention (Matthes 1943:257-258). Even when rulers were convinced of the need to convert, they often asked for a grace period during which they could have a mighty feast of all their domestic pigs (Jones 1979:148; Volkman 1985:21). 
In the period 1540-1640 the boundary of Islam became particularly clear as a result of the military and commercial struggle with Portuguese and Spanish Catholics. Acceptance of Islam came to be seen as a test of political loyalty; non-Muslim ethnic groups were seen not simply as latent Muslims but as actual or potential enemies; the state greatly increased its commitment to upholding orthodoxy. This period of conscious competition was one of such profound religious change that it might rightly be labelled not only conversion, but revolution. That sharp boundary of the house of Islam softened when the Dutch (and later English) insulated Southeast Asia from both counter-reformation Catholicism and international Islam, and divorced the religious contest from the economic one. The tendency grew to accept existing Austronesian society as Islamic rather than seek to change it (Reid 1993).

The discontinuity represented by Islam in that period of rapid change was most obvious to outsiders in matters that bore on identity - dress, speech, deportment and diet. There were, however, two areas in which Islam (and in different degrees Christianity) represented an even more fundamental challenge to Austronesian values. In its attitude to both sexuality and death Islam offered so basic an opposition to the ways of understanding the world that tensions persist until today, even though major changes were already evident from the sixteenth century.

Austronesian religion had understood the cosmos in terms of dualities in which both male and female elements were essential. Women had crucial ritual and religious roles, especially in mediating between humans and spirits. Islam and Catholic Christianity by contrast were carried by male religious specialists ministering to a deity identified as male. Spiritually talented and ritually experienced women could not find a place in the new religion to match that which they had played in the old.

It must have seemed to many women that Islam was a male ritual activity not relevant to women. Women in the Philippines were not given the option of ignoring Catholicism in this way, however, since the Spanish friars tended to seek out and persecute female shamans where Muslims were more inclined to ignore them (Schumacher 1979:72-73; Chirino 1604:302-305). Resistance to Islam in South Sulawesi appears to have had support from a few aristocratic women. Women of ordinary birth, however, were probably under little pressure to abandon domestic ritual activity, and even shamanistic healing. The chief evidence for this is less in the sources than in Southeast Asian religious practice, where such activities survived surprisingly well until this century. There is a curious story in the Babad Lombok (1979:17-19), however, that when all the men of Lombok submitted to a superior Javanese force and agreed to be circumcised, the women did not. Fearful that the women's refusal to convert would enrage 
the Javanese, the ruling circle moved their capital away from the coast and back to the ancient Hindu capital, though their commitment to Islam remained.

The struggle of Islam to impose a radically different sexual morality on Austronesians was a long one, with rapid changes in periods of orthodox emphasis but also inevitable compromise with the autonomous position of Austronesian women. Women had been accustomed to initiating divorce with little stigma attached. In the Philippines one high-born lady protested to a Spanish missionary that "it was a hard thing if unhappy with one's husband one could not leave him, as was the custom among them" (Chirino 1604:313). Unlike Catholicism, Islam of course permitted divorce, but only in terms of repudiation (talak) of the woman by the man. This formula was incorporated into local law codes as a legal option (Undang-undang Melaka 1976:132-133), but since women continued to be economically self-sufficient the frequency of divorce initiated by women was almost unparalleled. As an Arab visitor complained, the Malays "do not treat divorce as a religious act" (Ibn Majid 1462:206).

Adultery was already punished in very varied ways before Islam, and the harsh Islamic punishments for zina were adopted by the élite of some trading cities in the seventeenth century. Around 1600 foreigners witnessed the death penalty being publicly administered to élite youngsters in Patani, Aceh and Brunei - something much less common two centuries later. For rape and adultery the local law codes frequently added the much harsher Islamic penalties at the end of a passage setting out the system of moderate fines preferred by local custom (Reid 1988:156-158). In all these respects, there appears to have been a dramatic lurch towards Islamic norms during the period of conversion, followed by a reversion towards an accepted compromise with Austronesian reality.

Dress in public was one of the quickest things to change with Islam, as with Christianity. Bare breasts, penis inserts, tattoos and long male hair all disappeared very quickly in favour of what we now see as standard Indonesian/Malay dress of sarung and kebaya (chemise). Again the initial change was particularly dramatic. In Makassar city only fifty years after the conversion to Islam women were sometimes "entirely covered from head to foot, in such fashion that not even their faces can be seen" (Rhodes 1653:207). In Banten in the same period Arab-style dress became common (Schrieke 1957:242). Such un-Austronesian phenomena disappeared, however, along with the large Islamic merchant cities in the late seventeenth century.

Islam was even more uncompromising in its condemnation of idolatory, and for this reason required that the dead be buried quickly and simply, in complete contrast to Austronesian tradition. Change in the externals of funerary practice was achieved astonishingly quickly. Burial sites of the tenth to sixteenth centuries have yielded valuable ceramics and gold items, buried with the dead in the 
Philippines and eastern Indonesia to ensure a comfortable passage to the afterlife. These end abruptly with the coming of Islam and Christianity. The elaborate feasting, designed to ensure the deceased endured this most dangerous transition and would not return to torment the living, was modified into a relatively simple burial.

One of the major appeals of the scriptural religions was that they loosened the grip of spirits on every aspect of daily life. The truly pious were strengthened against assaults by unsatisfied spirits. People continued to face illness and misfortune, however, and for these the actions of angry spirits of the dead appeared a more immediate and direct explanation than scriptural notions of sin (Hoskins 1987:150-151). Ordinary Javanese Muslims in Banten told Scott (1606:172-173) that God was good and would not hurt them, but the devil (by which they must have meant spirits, setan in Malay) was constantly doing them harm so they directed all their ritual activity to appeasing him.

Islam had already incorporated some helpful popular compromises by the time its greatest Southeast Asian gains were made. The period following the fall of Baghdad was one in which the Sufi orders (tariqa) became the major instruments for the extension of the faith. While the founders and saints of the Sufi orders had been learned visionaries seeking a direct path to union with God, at the popular level Sufism by the fifteenth century represented a means of linking the individual with the spiritual power (Ar. baraqa; Malay berkat) of holy men, apostles, rulers and other remarkable people. The power of these dead saints was invoked to help the living through the spiritual genealogy which linked each Sufi teacher to the venerated founder of his order, but also through visitations (ziyara) to the tombs of holy men, where offerings were frequently made.

Such practices were particularly popular in Southeast Asia, where the berkat of dead saints could be invoked for similar purposes to the spirits of the ancestors. The newly Muslim population made pilgrimages and offerings at holy tombs those of the apostles thought to have introduced Islam to each area, such as the nine walis of Java or Dato ri Bandang in Makassar; of popularizers of the Sufi orders like Abdurrauf of Singkil, in Aceh, and Shaikh Yusuf of Makassar; and of certain powerful kings such as Iskandar Muda in Aceh. The strength of this saint-veneration as early as the sixteenth century is confirmed by the protest of a strictly orthodox Javanese handbook against it: "It is unbelief to say that the great imams are superior to the prophets, or to put the saints (wali) above the prophets, and even above our lord Muhammad" (Drewes 1978:38-39).

There is no doubt that despite rapid acceptance of the form of Muslim funerals, Southeast Asians continued to fear that the dead would trouble them unless ritually satisfied. In Banda in 1599, the dead were quickly buried in a white cloth, as prescribed, but when the Dutch asked Bandanese why they 
continued to pray for several days at the graveside they were told it was to prevent the dead from "standing up", which would otherwise surely happen causing great misfortune to all (Tweede Schipvaart 1601:90). Austronesians adopted with particular enthusiasm the widespread Muslim practice of returning at the third, seventh, fortieth and hundredth days after the burial, to feast at the grave (Martin 1604:49; Gervaise 1701:140-147; Raffles 1817 I:327; Ali Haji 1866:76).

According to the official or learned conception this is done in order to bestow on the deceased the recompense earned by his good work; according to the popular notion it is to let them enjoy the actual savour of the good things of the feast (Snouck Hurgronje 1893 I:221).

Honouring the dead has continued to be a great preoccupation of Southeast Asian Muslims. Whereas in the Arab world the seventh month of the Muslim year is considered most appropriate for such commemoration, in Indonesia it is the beginning and end of the fasting month (the ninth) when ancestors are especially remembered. Feasts were (and in some places still are) held at grave sites just before the fast commences, and at its end, and the forgiveness of elders is asked - the dead as well as the living. Although the origins of these practices lie in obscurity, they may initially have represented another creative Muslim response to the need to make offerings to the spirits of the dead.

Arabic terms and prayers were adopted quickly even for purposes which had been closely associated with the spirits. Do'a became the standard term for an invocation or a blessing to ward off evil (Houtman 1603:107, 165). Roh (plural arwah) was accepted as a Muslim equivalent of the Austronesian concept of semangat (soul-substance or spirit - Endicott 1970:28-51), while potent graves were referred to by Arabic words which reinterpreted their power in Islamic terms - kramat (sacred [grave]), berkat (spiritual power), and ziarah (pilgrimage - Houtman 1603:250).

\section{The Idea of the Sacred}

When we move from the externals which could be observed by outsiders to the belief systems of individual Austronesians, it must be immediately acknowledged that the sources are inadequate to allow us to confirm or deny any of the great hypotheses about religious change. Yet to dodge it is in a sense to trivialize one of the most momentous intellectual passages for an individual or a society into a matter of outward social conformity. I have little doubt that there was a large-scale movement towards a more modern mentalité in the fifteenth and sixteenth centuries, ${ }^{1}$ but it is almost impossible to explicate this without frequent reference to religious change at a much later period when there were ethnographers to record it. 
The religions of the Austronesians were characterized by a baffling diversity of spirits and practices. When the Dutch attempted to investigate the religion of Seram (central Maluku) in 1684, their conclusion was that "the informants differed so widely that it was impossible to describe the system, and moreover they are so superstitious that it would almost take a book of paper to note the details of each negeri" (cited Knaap 1987:71). Modern ethnographers have faced similar difficulties. Conklin discerned 1500 distinct spirits among the Ifugao (Luzon), and Volkman (1985:34) "perhaps thousands" among Toraja. This has not prevented either contemporary missionaries and observers or modern scholars from identifying an underlying pattern of Austronesian or Southeast Asian belief.

As in other pre-modern traditions, there was no distinction between a religious and a secular dimension. The material world was suffused with spiritual forces, and to survive and flourish in it everybody had to know how to manipulate them. In a sense it is modern religions, notably Christianity, Judaism, and modernist Islam, by largely abandoning their "functions of explanation, prediction and control" of everyday events, and withdrawing to an other-worldly personal piety where they do not compete directly with scientific understandings of nature (Horton 1971:104), which created the category "primitive religion". The older religious systems of the Austronesians, on the other hand, can only be understood as intimately involved in every significant event of daily life (for modern explanations, see Hoskins 1987:139; Volkman 1985:33). Ritual and shamanistic activity was usually designed for immediate practical ends. Spiritual forces had to be manipulated to cure illness, ensure fertility, increase power, safeguard the living particularly at dangerous life crises, and ensure that the dead were assisted through the most traumatic of all transitions into a contented afterlife. Feasting and animal sacrifice was made to ensure the spirits were on side for every personal crisis, including

the recovery of a sick person, the prosperous voyage of those embarking on the sea, a good harvest in the sowed lands, a propitious result in wars, a successful delivery in childbirth, and a happy outcome in married life (Plasencia 1589:191).

Even when Filipinos wanted to pick a fruit from a tree, plant or harvest rice, cross a stream or pass any major landmark, they would ask permission from the protective spirit and make some appropriate offering (Chirino 1604:298-299; Ortiz 1731, cited Rafael 1988:112). European observers were struck by the feasts and offerings to the spirits of the dead to aid the sick, and the attribution of illness and premature death to incorrect ritual or malign manipulation of the spirit world by some enemy.

In the African context, Horton (1971:101) has described a two-tier cosmology in which "lesser spirits" controlled the affairs of the local community, while a 
"supreme being" presided remotely over the entire cosmos. The supreme being was of greater interest to Africans who were drawn out of the local society for reasons such as trade, administration or enslavement, but for those immersed in the settled agricultural community had little role. Southeast Asia too had a concept of a somewhat remote creator, often named with reference to Sanskrit terminology - Batara Guru (Betala in Tagalog) or dewata - even though grounded in a specifically local mythology. Muslim and Christian missionaries naturally took special interest in these shadowy notions of a supreme creator god, but declined to use them to translate their own awesome concepts. Arabic Allah and Spanish Dios became the terms for God in Malay and Tagalog respectively. For older uses such as validating oaths, however, older terms seemed to carry more weight, especially in Javanese, Bugis and Makassarese (Noorduyn 1955:279; Andaya 1981:107-112).

Horton (1971) makes the point for Africa that even without new religions larger numbers of people would have directed their attention and ritual to the high god as the expansion of trade, communication and writing rendered local spirits unhelpful. The religion of spirits was not readily portable, and those who moved into the cosmopolitan trading cities had need of a personal faith which was universally valid. A similar point has been made for northern Thailand by O'Connor (1989), and for Sumba by Hoskins (1987:146).

The way in which the rulers of Wajo and Tallo', the two most commercialized states in South Sulawesi, moved towards monotheism before they accepted Islam (Noorduyn 1955:262-263; Reid 1981:14-15) suggests a similar kind of interpretation.

In a period of dynamic commercialization and urbanization, the consistency of scriptural monotheism was as much an advantage as its portability. Christian missionaries presented overwhelming evidence of the real terror in which many Austronesians lived because of the demands of malevolent spirits, and saw their task as the casting out of these demons in the name of Christ (Chirino 1604:300; Velarde 1749:71). Islam did not share this desire to make war on the spirits, since good djinn as well as bad were familiar themes. But Islam offered a refuge from the domination of these demanding spirits in a different vision of the cosmos. This was a predictable, moral world, in which the devout would be protected by God from all that the spirits could do, and would eventually be rewarded by an afterlife in paradise. Even the poor and the powerless, whose suffering at the hands of the spirits might not end with death, could hope to be rewarded in a Muslim heaven if they lived lives of personal virtue.

This new vision must have encouraged what Weber characterized as a rationalization of religion, or an "increase in distance ... between man and the sacred" (Geertz 1973:174). It depended on a simple but consistent concept of eternal reward and punishment, graphically illustrated in the Koran and much 
other Islamic literature. Preachers of both Islam and Christianity rendered into Austronesian vernaculars the torments which awaited in hell those foolish enough to prefer earthly pleasures to their eternal welfare, and those who rejected the true faith for its rivals (see examples in Rafael 1988:179-184; Hamzah Fansuri, Poems 1986:76, 92, 132).

Although the prominence of heaven and hell were new, the concepts may not have been. In their desire to find evocative terms to translate the Muslim and Christian heaven, proselytists made use of already localized words. Malay-speaking Muslims adopted the Sanskrit swarga, the abode of Siva, and naraka for heaven and hell respectively (Malay surga and neraka). The Spanish used Tagalog langit (sky) or other terms implying profound peace and contentment when discussing the joys of heaven.

In a moral universe, individuals provided heroic examples of moral and spiritual eminence. The ascetism of the Muslim sufis was particularly appealing because it shared elements already familiar from Indian traditions. The closeness of the Sufi saint to God was popularly thought to be evident in his supernatural powers and the bright glow (Malay cahaya, personalizing Arabic nur) which suffused him. The writers of Malay histories certainly believed that these self-evident powers were sufficient to convert many (Sejarah Melayu 1612:129; Hikayat Banjar 1968:420), and external sources confirm that at least such outstanding Sufi masters as Hamzah Fansuri, Syamsud-din as-Samatrani and Abdurrauf of Singkel in Aceh, and Shaikh Yusuf in Makassar and Banten, were popularly revered even during their lifetimes.

There must have been few if any Austronesians who doubted that spirits continued to interfere with the living. But Islam and Christianity provided predictable channels to tame them and scholarly traditions within which to pursue explanatory problems in a rational framework.

\section{Post-script}

I have argued elsewhere (Reid 1993a) that Islam also wrought changes, more slowly, in the Southeast Asian attitude to political power, tending to encourage greater concentrations of power in certain radically reforming rulers. Change in this, as in other respects, was neither all of a piece nor gradual and imperceptible. Islamization provided the potential for radical change by introducing an external set of ideals to which radical reformers could appeal with spasmodic hope of success. Some of the most radical changes came in the sixteenth and early seventeenth centuries, because socio-economic conditions gave sustenance to such radical visionaries (Reid 1993). Later phases of traumatically rapid socio-economic change occurred around the turn of the twentieth century, and in the 1970s and 1980s, giving further fuel to what is today often called 
fundamentalism. The Austronesians of Southeast Asia are no more inclined than anybody else, however, to sustain such idealisms over lengthy periods.

\section{References}

Ali Haji ibn Ahmad, Raja

1866 The precious gift (Tuhfat al-Nafis). Trans. Virginia Matheson and Barbara Andaya. Kuala Lumpur: Oxford University Press, 1982.

Andaya, Leonard

1981 The heritage of Arung Palakka: a history of South Sulawesi (Celebes) in the seventeenth century. The Hague: Nijhoff for Koninklijk Instituut voor Taal-, Land- en Volkenkunde.

Babad Lombok (ed.)

1979 Lalu Wacana. Jakarta: Departemen Pendidikan dan Kebudayaan Republik Indonesia.

Babad Tanah Jawi

1987 Babad Tanah Djawi: Javaansche Rijkskroniek. W. L. Olthof's vertaling van de prozaversie van J. J. Meinsma lopende tot het jaar 1721. Revised edition by J. J. Ras. Dordrecht: Foris for Koninklijk Instituut voor Taal, Land- en Volkenkunde.

Blair, E. H. and J. A. Robertson (eds)

1903-9 The Philippine islands, 1493-1898. Cleveland: Arthur H. Clark, 55 vols. Chirino, Pedro

1604 Relación de las Islas Filipinas: the Philippines in 1600. Trans. Ramón Echevarria. Manila: Historical Conservation Society, 1969.

Couto, Diego do

1645 Da Asia. 9 Decades. Lisbon: Regia Officina Typografica, 1778-88. Reprinted Lisbon, 1974.

Dampier, William

1697 A new voyage round the world. Sir Albert Gray (ed.). London: Argonaut, 1927.

Dias, Bathasar

1559 Letter from Melaka 3 December 1559. In H. Jacobs (ed.) Documenta Malucensia, Vol. I, pp.301-307. Rome: IHSI, 1974.

Diaz, Casimiro 
1718 Conquests of the Fillipinas islands. Translated in E.H. Blair and J.A. Robertson (eds) The Philippine Islands, 1493-1898, 41:317-324. Cleveland: Arthur H. Clark, 55 vols.

Drewes, G.W.J.

1978 An early Javanese code of Muslim ethics. The Hague: Nijhoff for Koninklijk Instituut voor Taal-, Land- en Volkenkunde.

Endicott, K.M.

1970 An analysis of Malay magic. Oxford: Clarendon Press.

Geertz, Clifford

1973 The interpretation of cultures. New York: Basic Books.

Gervaise, Nicolas

1701 An historical description of the kingdom of Macassar in the East Indies. London: Tho. Leigh. Reprinted Farnborough, 1971.

Hamzah Fansuri

1986 Poems. The poems of Hamzah Fansuri. G.W.J. Drewes and L.F. Brakel (eds). Dordrecht: Foris for Koninklijk Instituut voor Taal-, Land- en Volkenkunde.

Hikajat Bandjar

1968 Hikajat Bandjar: a study in Malay historiography. In J.J. Ras, pp.228-521. The Hague: Nijhoff for Koninklijk Instituut voor Taal-, Land- en Volkenkunde.

Hikayat Patani

1970 Hikayat Patani. The story of Patani. A. Teeuw and D.K. Wyatt (eds), Vol. I. The Hague: Koninklijk Instituut voor Taal-, Land- en Volkenkunde.

Horton, Robin

1971 African conversion. Africa 41(2):85-108.

Hoskins, Janet

1987 Entering the bitter house: spirit worship and conversion in West Sumba. In Rita Smith Kipp and Susan Rodgers (eds) Indonesian religions in transition, pp.136-160. Tucson: University of Arizona Press.

Houtman, Frederick de

1601 Cort Verhael. In W.S. Unger (ed.) De oudste reizen van de Zeeuwen naar Oost-Indie, 1598-1604, pp.64-111. The Hague: Nijhoff for LinschotenVereniging, 1948. 
1603 Le 'Spraeck ende woord-boek' de Frederick de Houtman. D. Lombard (ed.). Paris: Ecole française d'Extrême-Orient, 1970.

Ibn Majid, Ahmad

1462 al-Mal'aqiya. Trans. in G.R. Tibbets, A study of the Arabic texts containing material of South-east Asia, pp.99-206. Leiden: E.J. Brill for the Royal Asiatic Society, 1979.

Jones, Russel

1979 Ten conversion myths from Indonesia. In Nehemia Levtzion (ed.) Conversion to Islam, pp.29-58. New York: Holmes \& Meier.

Knaap, Gerrit

1987 Kruidnagelen en Christenen: De Verenigde Oost-Indische Compagnie en de bevolking van Ambon 1656-1696. Dordrecht: Foris for Koninklijk Instituut voor Taal-, Land- en Volkenkunde.

Lavezaris, Guido de

1574 Reply to Rada's opinion. In E.H. Blair and J.A. Robertson (eds) The Philippine islands, 1493-1898, III: 260-271. Cleveland: Arthur H. Clark, 55 vols.

Legazpi, Miguel López de

1569 Relation of the Filipinas islands, and of the character and conditions of their inhabitants. July 1569. In E.H. Blair and J.A. Robertson (eds) The Philippine islands, 1493-1898, 3:54-61. Cleveland: Arthur H. Clark, 55 vols.

Levtzion, Nehemia (ed.)

1979 Conversion to Islam. New York: Holmes \& Meier.

Lombard, Denys

1990 Le carrefour javanais. Essai d'histoire globale, 3 vols. Paris: Editions de l'École des hautes études en science sociales.

Manguin, Pierre-Yves

1979 L'introduction de l'Islam au Campa. Bulletin l'École française d'ExtrêmeOrient 66:255-269.

Martin, François

1604 Description du premier voyage faict aux Indes Orientales par les Français de Saint-Malo. Paris.

Matthes, B.F.

1943 Dr Benjamin Frederick Matthes: Zijn leven en arbeid. H. van den Brink (ed.). Amsterdam: Nederlandsch Bijbelgenootschap. 
Matelief, Cornelis

1608 Historische verhael vande treffelijcke reyse, gedaen near de Oost-Indien ende China. In I. Commelin (ed.) Begin ende Voortgangh va de Vereenighde Neederlandtsche Geoctroyeerde Oost-Indische Compagnie. Amsterdam 1646. Reprinted Amsterdam 1974.

Noorduyn, J.

1955 Een achttiende-eeuwse kroniek van Wadjo': Buginese historiografie. The Hague: Smits.

Pigafetta, Antonio

1524 First voyage round the world, pp.1-108. Trans. J.A. Robertson. Manila: Filipiniana Book Guild, 1969.

Pinto, Fernao Mendes

1578 The travels of Mendes Pinto. Trans. Rebecca Catz. Chicago: University of Chicago Press, 1989.

Pires, Tomé

1515 The Suma oriental of Tomé Pires. Trans. A. Cortesão. London: Hakluyt, 1944.

Plasencia, Juan de

1589 Relation of the worship of the Tagalogs, their Gods, and their burials and superstitions. In E.H. Blair and J.A. Robertson (eds) The Philippine islands, 1493-1898, 7:185-196. Cleveland: Arthur H. Clark, 55 vols.

Rafael, Vicente

1988 Contracting colonialism. Translation and Christian conversion in Tagalog society under early Spanish rule. Ithaca: Cornell University Press.

Raffles, T.S.

1817 The history of Java, 2 vols. London: John Murray. Reprinted Kuala Lumpur, Oxford University Press, 1965.

Reid, Anthony

1981 A great seventeenth century Indonesian family: Matoaya and Pattingalloang of Makassar. Masyarakat Indonesia 8(1):1-28.

1988 Southeast Asia in the age of commerce, Vol. I: The lands below the winds. New Haven: Yale University Press.

1993 Islamization and Christianization in Southeast Asia: The critical phase, 1550-1650. In Anthony Reid (ed.) Southeast Asia in the early modern era. Ithaca: Cornell University Press. 
1993a Kings, kadis and charisma in the 17th century archipelago. In Anthony Reid (ed.) The making of an Islamic political discourse in Southeast Asia, pp.83-108. Clayton: Monash University Centre of Southeast Asian Studies.

Rhodes, Alexandre de

1653 Rhodes of Vietnam: The travels and missions of Father Alexander de Rhodes in China and other kingdoms of the Orient. Trans. S. Hertz. Westminster, Md: Newman Press, 1966.

Ricklefs, M.C.

1979 Six centuries of Islamization in Java. In Nehemia Levtzion (ed.) Conversion to Islam, pp.100-128. New York: Holmes \& Meier.

Robson, Stuart

1981 Java at the crossroads. Bijdragen tot de Taal-, Lande- en Volkenkunde 137. Schrieke, B.

1957 Indonesian sociological studies, Vol. II. The Hague and Bandung: Van Hoeve.

Schumacher, John N.

1979 Readings in Philippine church history. Quezon City: Ateneo de Manila.

Scott, Edmund

1606 An exact discourse of the subtitles, fashions, policies, religion, and ceremonies of the East Indians. In Sir William Foster (ed.) The voyage of Henry Middleton to the Moluccas, pp.81-176. London: Hakluyt Society, 1943.

Sejarah Melayu

1612 Romanized Malay text. In R.O. Winstedt (ed.) The Malay annals; or Sejarah Melayu. The earliest recension from MS No. 18 of the Raffles Collection in the Library of the Royal Asiatic Society, London. Journal of the Malayan/Malaysian Branch of the Royal Asiatic Society 16, iii (1938).

Sja'ir Perang Mengkasar

1963 The Rhymed chronicle of the Macassar war. C. Skinner (ed.). The Hague: Nijhoff for Koninklijk Instituut voor Taal-, Land- en Volkenkunde.

Snouck Hurgronje, C.

1893 The Achehnese, 2 vols. Trans. A.W.S. O'Sullivan. Leiden: E.J. Brill, 1906. Tweede Schipvaart

1601 De Tweede schipvaart der Nederlanders naar Oost-Indie onder Jacob Cornelisz van Neck en Wijbrant Warwijck, 1598-1600, Vol. II. J. Keuning (ed.). The Hague: Nijhoff for Linschoten-Vereeniging, 1942. 
The Austronesians: Historical and Comparative Perspectives

Undang-undang Melaka

1976 Undang-undang Melaka: The laws of Melaka. Liaw Yock Fang (ed.). The Hague: Nijhoff for Koninklijk Instituut voor Taal-, Land- en Volkenkunde.

Velarde, Pedro Murillo

1749 Jesuit missions in the seventeenth century. In E.H. Blair and J.A. Robertson (eds) The Philippine islands, 1493-1898, 7:27-119. Cleveland: Arthur H. Clark, 55 vols.

Volkman, Toby

1985 Feasts of honor. Ritual and change in the Toraja Highlands. Urbana: University of Illinois Press.

Winstedt, Richard

1969 A history of classical Malay literature, 2nd ed. Kuala Lumpur: Oxford University Press.

Wolters, O.W.

1970 The fall of Srivijaya in Malay history. London: Lund Humphries.

\section{Notes}

${ }^{1}$ The case for this is strongly made by Denys Lombard (1990, II:131-175). 